\title{
Nitrogen cycling in high-input versus reduced-input arable farming
}

\author{
H. G. VAN FAASSEN \& G. LEBBINK \\ Institute for Soil Fertility Research, P.O. Box 30003, NL 9750 RA Haren, Netherlands \\ Received 1 March 1990; accepted 4 May 1990
}

\begin{abstract}
A comparison is made of a high-input and two reduced-input farming systems with a rotation of winter wheat - sugar beet - spring barley - potatoes on a calcareous silt loam soil. Nitrogen balance sheets for the growing seasons of 1986-1988 showed $\mathrm{N}$ deficits of 0-170 kg $\mathrm{ha}^{-1}$, suggesting substantial $\mathrm{N}$ losses to the environment.

The uncertainty about actual $\mathrm{N}$ losses mainly depended on the uncertainty of estimated net $\mathrm{N}$ mineralization. Periods with much rainfall in 1987 and 1988 , inappropriate use of animal manure and soil compaction may partly account for the heavy $\mathrm{N}$ losses in all three farming systems. Potential rates of $\mathrm{N}$-cycle processes were studied over the years to observe effects of changes in management. To increase the efficiency of mineral and organic $\mathrm{N}$ inputs, and to decrease $\mathrm{N}$ losses, soil inorganic- $\mathrm{N}$ concentrations should be kept low, especially in periods when losses are likely to occur.
\end{abstract}

Keywords: $\mathrm{N}$ balance, $\mathrm{N}$ cycling, $\mathrm{N}$ mineralization, $\mathrm{N}$ immobilization, denitrification, microbial biomass

\section{Introduction}

The following problems with high-input arable farming in the Netherlands led to the establishment of the Dutch Programme on Soil Ecology of Arable Farming Systems (Brussaard et al., 1988):

- contamination of groundwater by nitrate and of the atmosphere by $\mathrm{NH}_{3}$ and possibly $\mathrm{N}_{2} \mathrm{O}$ due to high inputs of fertilizers and manures,

- high costs and unwanted environmental effects due to abundant use of chemicals for crop protection, weed control and soil fumigation,

- deterioration of soil structure due to the use of heavy machinery, which necessitated intensive soil tillage.

The Programme's hypothesis is that a change from 'conventional' (high input) to 'integrated' (reduced input) farm management can improve:

- nutrient use efficiencies,

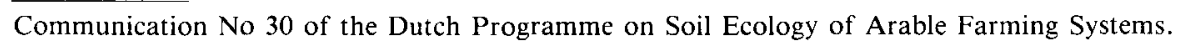


- control of pests, diseases and weeds,

- soil structure, with fewer negative effects on the environment.

Integrated management might give lower crop yields than conventional management, but because of lower costs the profitability to the farmer could be similar.

Agroecosystems are inherently more 'leaky' than undisturbed natural ecosystems, where vegetation is continuously present. Increased inputs of nitrogen into agriculture have greatly increased crop ( $\mathrm{N}$ ) outputs, but they have also increased $\mathrm{N}$ losses to the environment (Kolenbrander, 1982). $\mathrm{N}$ losses to the environment may increase strongly when $\mathrm{N}$ fertilization becomes higher than a certain threshold value, often near the optimum for crop production (Prins et al., 1988). The risk of $\mathrm{N}$ losses to the environment can be reduced by avoiding peak concentrations of inorganic $\mathrm{N}$ $\left(\mathrm{N}_{\mathrm{i}}\right)$ in soil, e.g. by split application of fertilizer. When $\mathrm{N}_{\mathrm{i}}$ fertilization of crops is decreased and partially replaced by organic manures, $\mathrm{N}$ mineralization by soil organisms becomes more important for the $\mathrm{N}$ supply of the crops (Lopez-Real, 1986). Use of organic manure will increase the pool of labile soil organic $\mathrm{N}$; losses of $\mathrm{N}$ mineralized from this pool should be avoided by using green manures and by stimulating $\mathrm{N}$ immobilization during periods with little or no $\mathrm{N}$ uptake by a crop.

In this paper, $\mathrm{N}_{\mathrm{i}}$-balance calculations covering the growing season will be discussed as well as changes in soil $\mathrm{N}$ mineralization rate, in $\mathrm{N}$ uptake by the crop, and in $\mathrm{N}$ losses due to changes in management. A conventional farming system was compared with two integrated systems, each system with the same rotation of winter wheat, sugar beet, spring barley and potatoes on a silt loam soil. The main differences in management are given in Table 1 (Brussaard et al., 1988; Kooistra et al., 1989). Soil physical conditions and meteorological data necessary to account for some of the differences in overall $\mathrm{N}$ budget will be discussed.

Table 1. Main differences between 'conventional', 'integrated' and 'integrated with minimum tillage' management systems.

\begin{tabular}{|c|c|c|c|}
\hline & Conventional & Integrated & $\begin{array}{l}\text { Integrated with } \\
\text { minimum tillage }\end{array}$ \\
\hline $\begin{array}{l}\text { Inorganic N } \\
\text { fertilization }\end{array}$ & As $\mathrm{Ca}\left(\mathrm{NO}_{3}\right)_{2}$ & Less than conventional & As integrated \\
\hline $\begin{array}{l}\text { Organic N } \\
\text { fertilization }\end{array}$ & $\begin{array}{l}\text { Crop residues } \\
\text { only }\end{array}$ & $\begin{array}{l}\text { Crop residues, } \\
\text { manure/compost }\end{array}$ & As integrated \\
\hline Crop protection & $\begin{array}{l}\text { Conventional use of } \\
\text { pesticides } \\
\text { including soil } \\
\text { fumigation }\end{array}$ & $\begin{array}{l}\text { Less than conventional; } \\
\text { no soil } \\
\text { fumigation }\end{array}$ & $\begin{array}{l}\text { As integrated, } \\
\text { but more use of } \\
\text { herbicides }\end{array}$ \\
\hline Tillage & $\begin{array}{l}20 \text { or } 25 \mathrm{~cm} \\
\text { ploughing }\end{array}$ & $\begin{array}{l}12 \text { to } 15 \mathrm{~cm} \\
\text { ploughing plus } \\
\text { subsoiling to } \\
20 \text { or } 25 \mathrm{~cm}\end{array}$ & $\begin{array}{l}5 \mathrm{~cm} \text { ploughing } \\
\text { or } 10 \mathrm{~cm} \\
\text { cultivator }\end{array}$ \\
\hline
\end{tabular}




\section{Materials and methods}

\section{Field data}

Field work was carried out at the experimental farm Dr H. J. Lovinkhoeve on a calcareous silt loam soil. Soil characteristics of the $0-25 \mathrm{~cm}$ layer were: $\mathrm{pH}-\mathrm{KC1} 7.5$; organic matter 2.2-2.8\%; total $\mathrm{N} 0.10-0.14 \% ; \mathrm{CaCO}_{3} 9 \%$, sand $12 \%$, silt $68 \%$, clay $20 \%$. Average annual rainfall during $1943-1987$ was $730 \mathrm{~mm}$. A previous experiment at the experimental site, in which three different input regimes of organic matter (A, B and C) were compared, was taken as a starting point. During the period 1966-1984, average annual inputs of organic matter were $5650 \mathrm{~kg} \mathrm{ha}^{-1}$ for variant A (crop residues, including ploughing down of a grass ley, and applications of farmyard manure), $3200 \mathrm{~kg} \mathrm{ha}^{-1}$ for variant B (crop residues only) and $5280 \mathrm{~kg} \mathrm{ha}^{-1}$ for variant $\mathrm{C}$ (crop residues and green manures). As a result, during 1981-1984 the A, B and C blocks had average organic matter contents of 2,8\%, $2,2 \%$ and $2,3 \%$, respectively. Four new variants were started in autumn 1985: conventional management on $50 \%$ of block $A$ (CONVA) and on $50 \%$ of block B (CONVB), and integrated management on $50 \%$ of block A (INTA) and on $50 \%$ of block B (INTB). In autumn 1986, integrated management with minimum tillage was started on block C (MTC) as a fifth variant (Fig. 1). All variants had the same crop rotation of winter wheat - sugar beet - spring barley - potatoes. Each variant or treatment consisted of four fields of $12 \times 85 \mathrm{~m}^{2}$, with each crop of the rotation being present each year in every variant. The MTC variant was started in duplicate, i.e. on eight fields, but because of nematode problems four fields (Nos 10-13) had to be disinfested and were returned to conventional practice in 1989. Every year

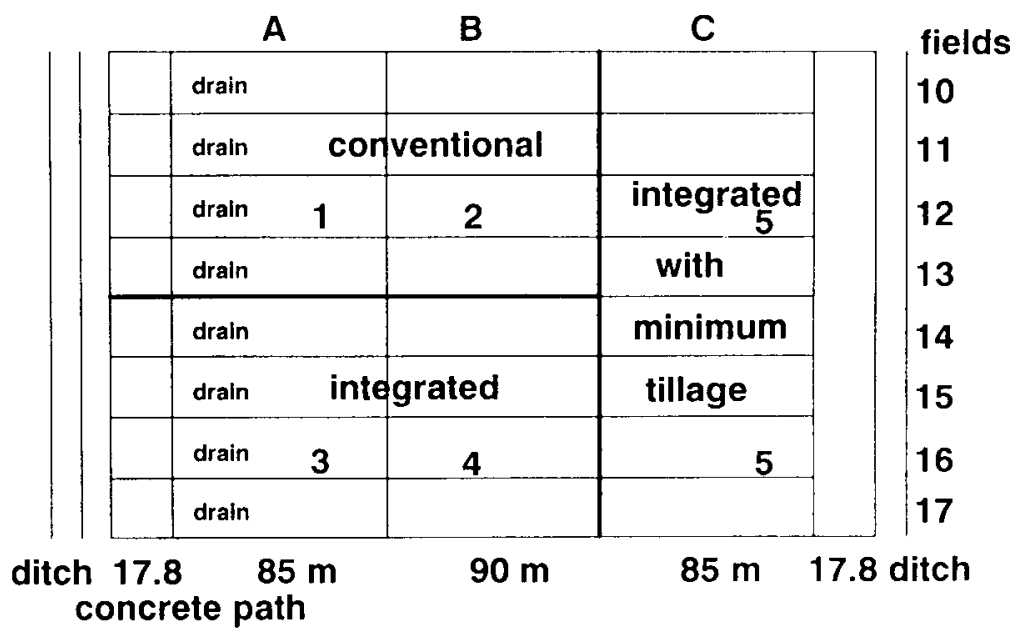

Fig. 1. The position of the new variants laid on the A, B, and C blocks of a previous long-term experiment, which had resulted in organic matter contents of about $2.8 \%, 2.2 \%$ and $2.3 \%$ for block $\mathrm{A}, \mathrm{B}$ and $\mathrm{C}$, respectively. 
for each field, crop yields and total-N contents of consumable and other plant parts were determined at harvest.

Detailed research work was done mainly on the variants CONVB and INTA (fields 12B and 16A). We expected only small changes in soil organic matter (SOM) and labile $\mathrm{N}$ pools of these variants, since the organic matter input would be changed little under the new management. The other variants, CONVA and INTB, were expected to show larger changes in their SOM and labile $\mathrm{N}$ pools and to reach new equilibrium levels after several years. Table 2 shows the recent cropping history of six fields studied, as well as their organic matter and total- $\mathrm{N}$ contents.

The following parameters were determined:

- dry matter and total-N content of the crop by harvesting two or three subplots (3-16 $\mathrm{m}^{2}, 4$ or 5 times during the growing season;

- mineral $\mathrm{N}$ extractable with $1 \mathrm{M} \mathrm{KCL}$, in six layers of the soil profile down to $1 \mathrm{~m}$, at the experimental harvesting dates; extracts were analysed using a Technicon autoanalyzer (Traacs 800); dichromate-oxidizable organic matter according to Kurmies, and total-N contents according to Deijs, annually in the layers $0-10,10-25$ and $25-40 \mathrm{~cm}$;

- meteorological parameters and soil physical conditions;

- root development (van Noordwijk, 1987).

$\mathrm{N}$ fertilization of conventional fields served to increase the amount of mineral $\mathrm{N}$ present in spring in the upper $60 \mathrm{~cm}$ (for winter wheat $100 \mathrm{~cm}$ ) of the soil to the level needed by the crop (Neeteson, 1989); it was often split over two or even three dressings.

Integrated fields received less $\mathrm{N}$ and part of it as organic manure (Fig. 4); the solid fraction of pig slurry ( $20 \mathrm{t} \mathrm{ha}^{-1}$, containing $24 \%$ dry matter and $0.85 \%$ total $\mathrm{N}$ ) was applied in the spring of 1987 to potato and sugar beet fields, and spent

Table 2. Recent cropping history, soil organic matter and total-N contents of six fields used in detailed studies. See Fig. 1 for the layout of the experiment.

\begin{tabular}{|c|c|c|c|c|c|c|c|c|c|}
\hline \multirow[t]{2}{*}{ Field } & \multirow[t]{2}{*}{ Variant ${ }^{1}$} & \multicolumn{6}{|c|}{ Year } & \multirow{2}{*}{$\begin{array}{l}\text { Organic } \\
\text { matter } \\
\text { content } 2,3 \\
(\%)\end{array}$} & \multirow{2}{*}{$\begin{array}{l}\text { Total N2 } \\
(\%)\end{array}$} \\
\hline & & 84 & 85 & 86 & 87 & 88 & 89 & & \\
\hline $12 \mathrm{~A}$ & CONVA & $1^{4}$ & $\mathrm{p}$ & ww & $\mathrm{sb}$ & $\mathrm{b}$ & $\mathrm{p}$ & 2.75 & 0.14 \\
\hline $12 \mathrm{~B}$ & CONVB & $\mathrm{p}$ & $\mathrm{sb}$ & ww & $\mathrm{sb}$ & $\mathrm{b}$ & $\mathrm{p}$ & 2.20 & 0.10 \\
\hline $16 \mathrm{~A}$ & INTA & $p$ & $\mathrm{sb}$ & ww & $\mathrm{sb}$ & $\mathrm{b}$ & $\mathrm{p}$ & 2.75 & 0.14 \\
\hline $16 \mathrm{~B}$ & INTB & ww & f & ww & $\mathrm{sb}$ & $\mathrm{b}$ & $\mathrm{p}$ & 2.30 & 0.11 \\
\hline $12 \mathrm{C}$ & MTC & $\mathrm{p}$ & sb & $\mathrm{b}$ & sb & $b$ & $\mathrm{p}$ & 2.35 & 0.11 \\
\hline $16 \mathrm{C}$ & MTC & ww & $\mathrm{f}$ & $\mathrm{p}$ & $\mathrm{sb}$ & $\mathrm{b}$ & $\mathrm{p}$ & 2.35 & 0.11 \\
\hline
\end{tabular}

1 Variants: CONVA $=$ conventional management on block $\mathrm{A}, \mathrm{CONVB}=$ conventional management on block B, INTA = integrated management on block A, INTB = integrated management on block B, $\mathrm{MTC}=$ integrated management with minimum tillage on block $\mathrm{C}$.

2 Average 1981-1984, 0-25 cm layer.

3 Organic matter $=1.724 \times$ oxidizable organic ' $\mathrm{C}$ '.

${ }^{4} \mathrm{p}=$ potatoes, $\mathrm{sb}=$ sugar beet, $\mathrm{w} w=$ winter wheat, $\mathrm{b}=$ spring barley, $1=$ grass ley, $\mathrm{f}=\mathrm{flax}$. 
mushroom compost (30 tha $\mathrm{th}^{-1}$, containing $35 \%$ dry matter and $0.7 \%$ total $\mathrm{N}$ ) was applied in the autumn of 1987 and 1988 on fields where sugar beet were grown in 1988 and in 1989, respectively; in spring 1989, a granular organic fertilizer ( $3 \mathrm{t}$ $\mathrm{ha}^{-1}$, containing $78 \%$ dry matter and $2,1 \%$ total $\mathrm{N}$ ) was applied to potato fields. The applied pig slurry solids, compost and granular organic fertilizer contributed per ha 3700,5300 , and $1800 \mathrm{~kg}$ organic matter, and 170,210 and $60 \mathrm{~kg} \mathrm{~N}$ (mainly organic $\mathrm{N})$, respectively.

\section{Inorganic- $N\left(N_{i}\right)$ balance calculations}

In the soil system the following balance applies:

$$
\text { Sum of } \mathrm{N}_{\mathrm{i}} \text { inputs }=\text { sum of } \mathrm{N}_{\mathrm{i}} \text { outputs }+\Delta \mathrm{N}_{\mathrm{i}} \text { - soil }
$$

where $\Delta \mathrm{N}_{\mathrm{i}}$ is the change in inorganic- $\mathrm{N}$ content of the soil.

Inputs can be fertilizer $\mathrm{N}_{\mathrm{i}}, \mathrm{N}_{\mathrm{i}}$ in precipitation, $\mathrm{N}_{\mathrm{i}}$ in manure, or $\mathrm{N}_{\mathrm{i}}$ from $\mathrm{N}$ mineralization. Outputs can be the $\mathrm{N}_{\mathrm{i}}$ taken up by the crop, by green manures or by weeds, $\mathrm{N}_{\mathrm{i}}$ losses to the environment (volatilization of $\mathrm{NH}_{3}$, denitrification and leaching) and immobilization of $\mathrm{N}_{i}$ in soil organic matter.

Inputs to compensate (estimated) outputs should take into account $\mathrm{N}_{\mathrm{i}}$ supplied to the crop by net mineralization of soil organic $\mathrm{N}$ or, in certain cases, the net immobilization of $\mathrm{N}_{\mathrm{i}}$.

All calculations are based on field and laboratory measurements described in this paper, except for $\mathrm{N}_{\mathrm{i}}$ in precipitation, for which data from a nearby weather station have been used.

\section{Laboratory studies}

In laboratory experiments, the mechanisms of some of the processes involved were investigated in more detail:

- Potential N-mineralization rates were measured by incubating moist homogenized soil samples for 1, 6 or 12 weeks (duplicates per soil layer), taken 4 or 5 times a year, including the experimental harvesting dates. Before and after incubation, samples were extracted with $1 \mathrm{M} \mathrm{KCl}$ and analysed for mineral $\mathrm{N}$ (ammonium and nitrate) using standard autoanalyzer methods. The increase in mineral $\mathrm{N}$ from 1 to 6 or 12 weeks incubation was used to calculate $\mathrm{N}$-mineralization rates. Mineral $\mathrm{N}$ after 1 week incubation is taken as the reference to compensate for a possible effect of homogenizing the samples. The soil samples were also used to determine $\mathrm{N}$ flushes by chloroform fumigation followed by 10 days incubation at $25^{\circ} \mathrm{C}$ (Jenkinson \& Powlson, 1976). The $\mathrm{N}$ flush, the difference in mineral $\mathrm{N}$ after incubation between fumigated and unfumigated control samples, was used as an estimate of $\mathrm{N}$ in microbial biomass.

- Separately, the effect of temperature on $\mathrm{N}$ mineralization was established by incubation of samples at 5,10 and $20^{\circ} \mathrm{C}$.

- Potential $\mathrm{N}$-mineralization rates of organic manures were also measured by incubating them with homogenized moist soil at 5,10 and $20^{\circ} \mathrm{C}$. 
- Structurally intact soil cores of $100 \mathrm{~cm}^{3}$, taken from the $0-5 \mathrm{~cm}$ layer in the field, were incubated at $20{ }^{\circ} \mathrm{C}$ in closed $370-\mathrm{cm}^{3}$ jars to measure potential $\mathrm{O}_{2}$ consumption rates. Sugar beet fields 12B, 12C, 16A and 16B were sampled four times from May to October 1987; eight samples were taken per field each time. Structurally intact soil cores of $0.75-1.0 \mathrm{dm}^{3}$, taken from the $0-13 \mathrm{~cm}$ layer of fields $12 \mathrm{C}$ and $16 \mathrm{~A}$ with steel cylinders with a cutting edge, were incubated in closed pots of about $1.5 \mathrm{dm}^{3}$ to measure potential $\mathrm{O}_{2}$ consumption and denitrification rates; 4 or 6 replicates were used at 3 sampling dates in 1987. Samples $\left(5 \mathrm{~cm}^{3}\right.$ of the headspace gases were taken with a syringe through a septum and analysed by gas chromatography (for $\mathrm{O}_{2}, \mathrm{CO}_{2}, \mathrm{~N}_{2} \mathrm{O}$ and $\mathrm{C}_{2} \mathrm{H}_{2}$ ). The production of $\mathrm{N}_{2} \mathrm{O}$, in the presence of added $\mathrm{C}_{2} \mathrm{H}_{2}$ (to a partial pressure of about $1 \mathrm{kPa}$ ) as an inhibitor of $\mathrm{N}_{2} \mathrm{O}$-reductase, was used as a measure of denitrification (Kroeze et al., 1989).

\section{Results and discussion}

\section{Inorganic- $N$ balance calculations}

The $\mathrm{N}_{\mathrm{i}}$ balance for winter wheat in 1986 showed a deficit of about $50 \mathrm{~kg} \mathrm{ha}^{-1}$ for field 16A (INTA), presumably lost by denitrification, and none for field $12 \mathrm{~B}$ (CONVB). This loss of $\mathrm{N}$ occurred probably in June, when crop demand for $\mathrm{N}$ was highest, and may account for the lower $\mathrm{N}$ output for field $16 \mathrm{~A}$. A very dry period in August 1986 caused early senescence of the crop and limited its further $\mathrm{N}$ uptake, whereas $\mathrm{N}$ mineralization continued which accounted for the amount of soil nitrate present at harvest, $\mathrm{N}_{\mathrm{e}}$ (Fig. 2a). $\mathrm{N}_{\mathrm{i}}$ balances for sugar beet in 1987 and for spring barley in 1988 showed large deficits (Fig. 2b, c), presumably losses due to nitrate leaching as well as denitrification and perhaps $\mathrm{NH}_{3}$ volatilization. Both 1987 and 1988 were very wet years (Fig. 3), which may largely account for the heavy $\mathrm{N}$ losses. In June 1987 and in July 1988, groundwater levels rose to $20-40 \mathrm{~cm}$ below the soil surface. Soil bulk densities of the $0-40 \mathrm{~cm}$ layers were relatively high in 1987 as well as in 1988, which may have furthered denitrification.

$\mathrm{N}$ losses early in the growing season make the crop more dependent on $\mathrm{N}$ supply from mineralization than in other years. Crops under integrated management may in such cases profit more from $\mathrm{N}$ supply by mineralization than crops under conventional management. When net $\mathrm{N}$ mineralization was overestimated, the $\mathrm{N}$ deficit overestimated the $\mathrm{N}$ losses.

\section{$N$ uptake, $N$ removal and $N$ recycling}

The amounts of nitrogen removed from the fields in the harvested products (grain and straw, beets and tubers) are shown in Figure 4, which also gives the amounts of inorganic and organic $\mathrm{N}$ applied. Although the amounts of $\mathrm{N}$ removed by specific crops in 1987 were quite different from those in 1988, the total amounts of $\mathrm{N}$ removed with the four crops were similar in these years for each of the five variants. Substantial amounts of $\mathrm{N}$ taken up by the crops and by green manures were returned to the soil as crop residues (roots, stubble, foliage, beet tops). $\mathrm{N}$ removal at harvest 

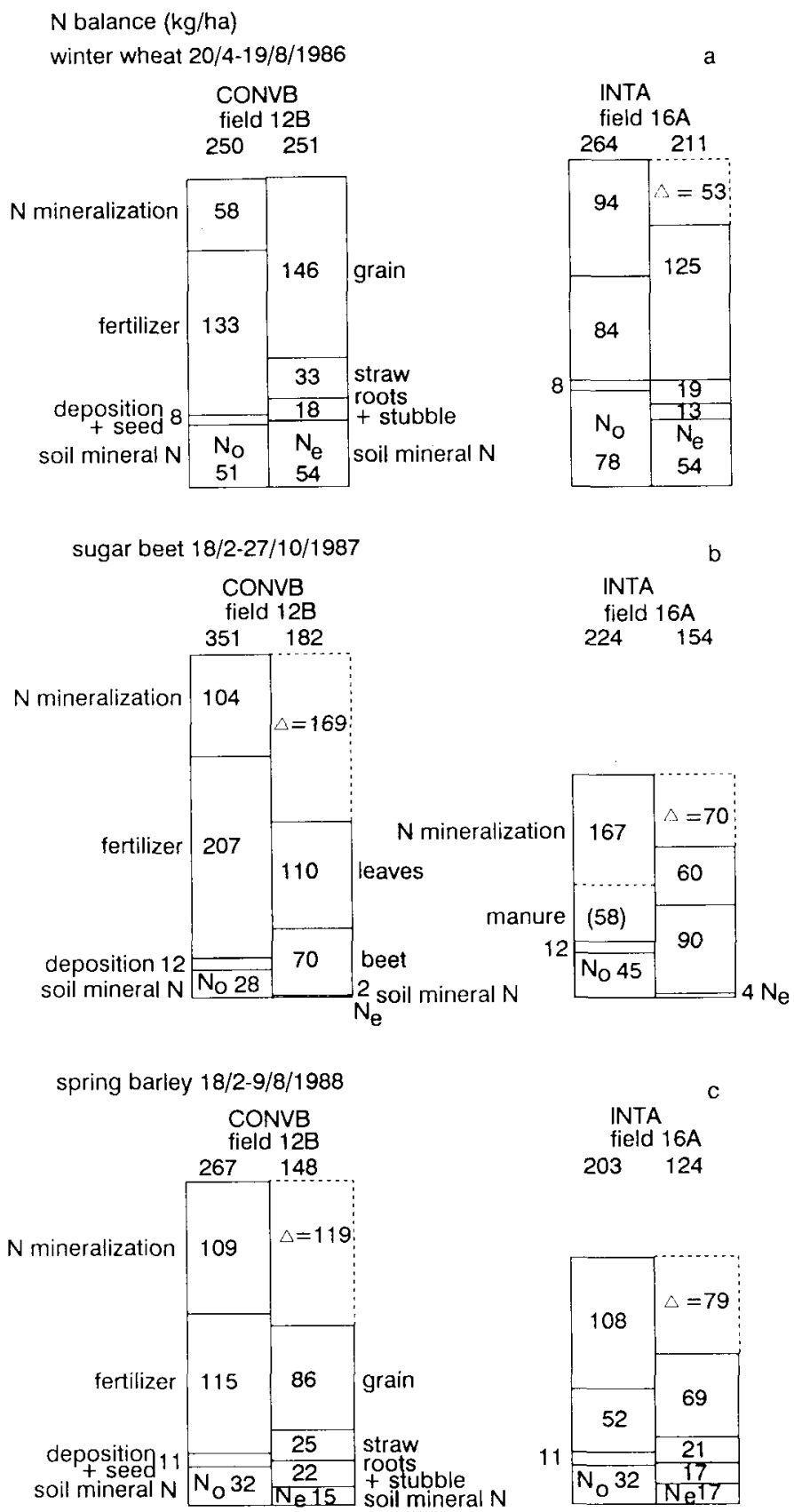

Fig. 2. Nitrogen balance sheets for field 12B under conventional management (CONVB) and for field 16A under integrated management (INTA). (a) Winter wheat (1986). (b) Sugar beet (1987). (c) Spring barley (1988). $\mathrm{N}_{\mathrm{o}}=$ soil mineral $\mathrm{N}$ at the start, $\mathrm{N}_{\mathrm{e}}=$ soil mineral $\mathrm{N}$ at the end of the balance period, in the $0-100 \mathrm{~cm}$ layer. 


\section{precipitation}

(mm per 10 days)
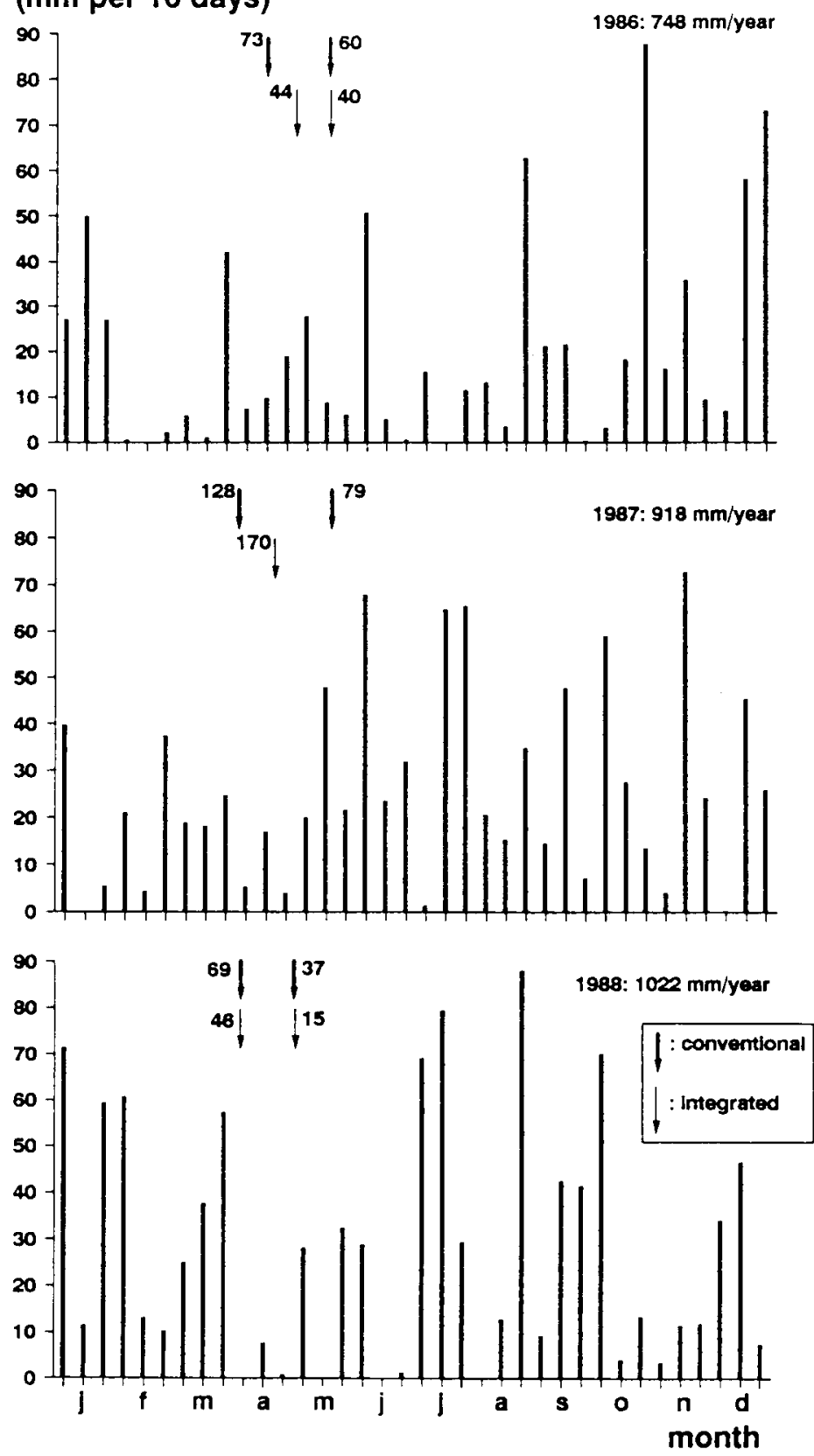

Fig. 3. Rainfall distribution during 1986-1988, with amounts of fertilizer-N or manure-N applied $(\mathrm{kg}$ $\mathrm{ha}^{-1}$ ) to fields 12B (CONV) and 16A (INT) indicated by arrows. 


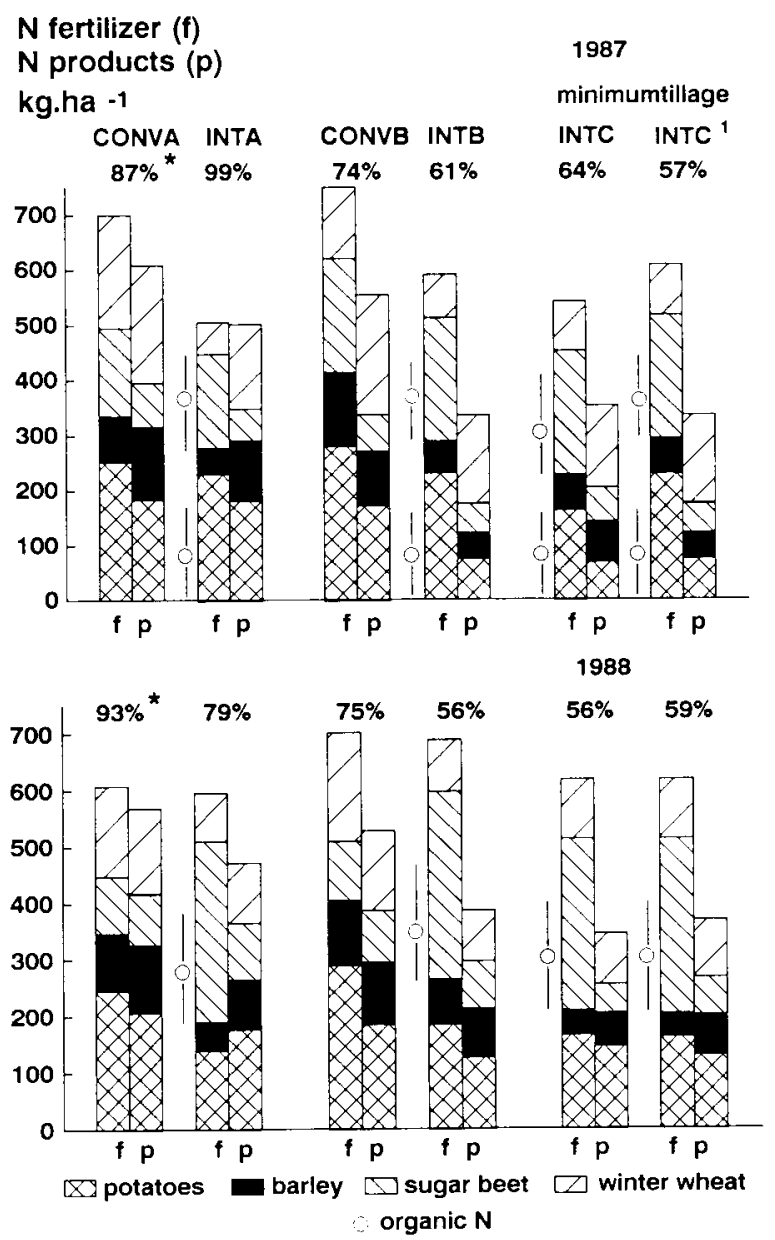

Fig. 4. Cumulative $\mathrm{N}$ fertilization and cumulative $\mathrm{N}$ removal with harvest products for the rotation in 1987 and 1988. ${ }^{*} \mathrm{~N}_{\mathrm{p}} / \mathrm{N}_{\mathrm{f}} \times 100 \% ; \mathrm{N}_{\mathrm{p}}=\mathrm{N}$ in products, $\mathrm{N}_{\mathrm{f}}=$ total- $\mathrm{N}$ from fertilizer and/or manure.

was largest in the case of conventional $\mathrm{N}$ fertilization. The lower amounts of $\mathrm{N}$ removed in the integrated variants were associated with lower crop yields (Table 3) and often lower $\mathrm{N}$ contents of the products (not shown). Yields under integrated management were acceptable compared with our aim of 80-90 \% of the conventional yields on block $B$. The minimum tillage variant did not yet reach that aim, as might be expected, since it was already known from another field experiment at the same site that this transition needed about 10 years to give optimum yields. Yields on block $\mathrm{A}$ were on average higher than on block $\mathrm{B}$, reflecting a long-term positive effect of the higher organic matter content on block $A$ than on block $B$.

$\mathrm{N}$ removed in harvested products as a percentage of $\mathrm{N}$ applied in fertilizers and manures (input/output ' $\mathrm{N}$-use efficiency') decreased as follows: CONVA $\geq$ INTA $>$ CONVB $>$ INTB $>$ INTC (Fig. 4). Variants on block A may have profited from 
Table 3. Crop yields $\left(t^{h a-1)}\right.$ in different years.

\begin{tabular}{|c|c|c|c|c|c|c|c|c|c|c|c|c|c|c|}
\hline \multirow[t]{2}{*}{ Variant $^{1}$} & \multicolumn{3}{|c|}{$\begin{array}{l}\text { Winter } \\
\text { wheat } \\
(\mathrm{DW})^{2}\end{array}$} & \multicolumn{3}{|c|}{$\begin{array}{l}\text { Sugar } \\
\text { beet } \\
\text { (sugar) }\end{array}$} & \multicolumn{3}{|c|}{$\begin{array}{l}\text { Spring } \\
\text { barley } \\
\text { (DW) }\end{array}$} & \multicolumn{4}{|c|}{$\begin{array}{l}\text { Potatoes } \\
(\mathrm{FW})^{3}\end{array}$} & \multirow{2}{*}{$\begin{array}{l}\text { Mean } \\
\text { relative } \\
\text { yield } \\
(\% \text { of } \\
\text { CONVB }\end{array}$} \\
\hline & 86 & 87 & 88 & 86 & 87 & 88 & 86 & 87 & 88 & 86 & 87 & 88 & 89 & \\
\hline CONVA & 7.6 & 6.5 & 6.3 & 13.5 & 9.3 & 11.2 & 6.4 & 4.9 & 4.8 & 48 & 52 & 55 & 67 & 104 \\
\hline CONVB & 7.5 & 6.7 & 5.7 & 13.4 & 9.3 & 11.5 & 5.9 & 4.6 & 4.6 & 45 & 46 & 48 & 69 & 100 \\
\hline INTA & 6.8 & 4.6 & 4.7 & 13.8 & 8.6 & 10.8 & 5.1 & 4.7 & 4.1 & 56 & 29 & 51 & 70 & 92 \\
\hline INTB & 6.3 & 5.7 & 3.7 & 12.7 & 7.3 & 10.4 & 4.9 & 4.1 & 4.2 & 45 & 26 & 35 & 55 & 83 \\
\hline MTC & - & 4.5 & 3.8 & - & 9.3 & 8.1 & - & 4.0 & 3.4 & - & 26 & 41 & - & 76 \\
\hline $\mathrm{MTC}^{4}$ & - & 5.8 & 3.1 & - & 7.6 & 7.0 & - & 2.9 & 3.2 & - & 24 & 43 & 50 & 70 \\
\hline
\end{tabular}

1 Variants: see Table 2.

2 DW $=$ grain dry weight.

$3 \mathrm{FW}=$ fresh weight.

4 Duplicate.

a higher $\mathrm{N}$ mineralization on block $\mathrm{A}$ than on block $\mathrm{B}$, related to the higher organic $\mathrm{N}$ content in block $\mathrm{A}$. The use of slowly mineralizable compost accounted for the lower N-use efficiencies of INT variants. Soil structure in block $\mathrm{C}$, which was in a transitional stage after the introduction of minimum tillage in autumn 1986, may have promoted $\mathrm{N}$ losses under wet conditions and may have impeded $\mathrm{N}$ uptake by the crop under dry conditions more rapidly than on block B (J. A. de Vos, unpublished).

Sugar beet and potatoes, with high levels of $\mathrm{N}_{\mathrm{i}}$ fertilization may give higher $\mathrm{N}$ losses than cereals. The longer the period between fertilization and start of rapid crop growth and $\mathrm{N}$ uptake, the greater is the risk of $\mathrm{N}$ losses.

\section{$N$ supply to the crop by mineralization}

Potential N-mineralization rates of soil organic- $\mathrm{N}$ and of manures increased almost linearly with temperature within the range $5-20^{\circ} \mathrm{C}$; this relationship was used to calculate temperature-corrected rates of $\mathrm{N}$ mineralization in the field. Mineralization rates calculated from 5 or 11 weeks incubation were linearly correlated $(r>0.9$, $P<0.01$ ) for samples from each of the fields 12B, 12C, 16A and 16B.

Potential $\mathrm{N}$-mineralization rates varied with time and were on average highest in field $12 \mathrm{C}$ with minimum tillage (Tables 4 and 5). Depending on the position of the crop residues, the potential $\mathrm{N}$ mineralization rate was highest in the $0-5,0-10 \mathrm{~cm}$ or 10-25 cm layer, and always low in the $25-40 \mathrm{~cm}$ layer. A higher rate of $\mathrm{N}$ mineralization in the $0-25 \mathrm{~cm}$ layers of the INT fields $16 \mathrm{~A}, 16 \mathrm{~B}$ and $12 \mathrm{C}$ partly compensated for a lower level of $\mathrm{N}$ fertilization on these INT fields than on CONV field 12B. Homogenizing the soil samples and optimum aeration may have caused a more rapid $\mathrm{N}$ mineralization than under field conditions and may have resulted in overestimation of $\mathrm{N}$ mineralization in the field. An improvement may be the incubation of cores with intact soil structure, but because of spatial variability in the field a 
Table 4. Average $\mathrm{N}$-mineralization rates of soil samples (mg N mineralized per kg dry soil in 5 weeks at $20^{\circ} \mathrm{C}$ ) taken from different fields (variants) at various depths over the years.

\begin{tabular}{|c|c|c|c|c|c|}
\hline \multirow{3}{*}{$\begin{array}{l}\text { Layer } \\
(\mathrm{cm})\end{array}$} & \multicolumn{5}{|c|}{ Year, period } \\
\hline & 1986 & 1987 & 1988 & 1987 & 1988 \\
\hline & Apr.-Aug. & May-Oct. & May-Aug. & May-Oct. & May-Aug. \\
\hline Field (variant)' & \multicolumn{3}{|c|}{$12 B(C O N V B)$} & \multicolumn{2}{|c|}{$12 C(M T C)$} \\
\hline $0-5$ & & & & 36 & 34 \\
\hline $0-10$ & 4.9 & 9.2 & 7.5 & 20 & 22 \\
\hline $10-25$ & 5.0 & 4.4 & 8.2 & 7.6 & 6.5 \\
\hline $25-40$ & 4.1 & 3.5 & 5.5 & 4.8 & 4.2 \\
\hline $40-100$ & 3.2 & - & - & - & - \\
\hline Field (variant) & \multicolumn{3}{|c|}{$16 A(I N T A)$} & \multicolumn{2}{|c|}{$16 B(M T C)$} \\
\hline $0-10$ & 13 & 19 & 10 & 18 & 9.0 \\
\hline $10-25$ & 8.1 & 8.0 & 12 & 6.2 & 12 \\
\hline $25-40$ & 2.8 & 3.8 & 4.0 & 3.4 & 3.2 \\
\hline $40-100$ & 2.1 & - & - & - & - \\
\hline
\end{tabular}

1 Variants: see Table 2.

Table 5. Mean potential $\mathrm{N}$-mineralization rates and mean $\mathrm{N}$-flushes for soil samples taken on eight dates in 1987 and 1988.

\begin{tabular}{|c|c|c|c|c|c|}
\hline \multirow[t]{3}{*}{$n^{3}$} & \multirow{2}{*}{$\begin{array}{l}\mathrm{N} \text {-mineralization } \\
\text { (mg N kg-1 dry soil) }\end{array}$} & \multirow[t]{3}{*}{$\mathrm{N}$-flush } & \multicolumn{3}{|c|}{ Coefficients of correlation $(r)$} \\
\hline & & & \multirow{2}{*}{$5 w / 11 w$} & \multirow{2}{*}{$5 \mathrm{w} / \mathrm{N}-\mathrm{fl}$} & \multirow{2}{*}{$11 \mathrm{w} / \mathrm{N}-\mathrm{fl}$} \\
\hline & 11 weeks & & & & \\
\hline
\end{tabular}

\begin{tabular}{|c|c|c|c|c|c|c|c|c|}
\hline Field 1 & Variant $^{2}$ & & & & & & & \\
\hline $12 \mathrm{~B}$ & CONVB & 24 & $6.6 \mathrm{a}^{4}$ & $12.3 \mathrm{a}$ & $10.1 \mathrm{a}$ & 0.935 & 0.214 & 0.360 \\
\hline $12 \mathrm{C}$ & MTC & 24 & $10.4 \mathrm{c}$ & $20.4 \mathrm{~b}$ & $13.8 \mathrm{~b}$ & 0.950 & 0.834 & 0.838 \\
\hline $16 \mathrm{~A}$ & INTA & 24 & $9.2 b, c$ & $19.5 \mathrm{~b}$ & $17.9 \mathrm{~b}$ & 0.920 & 0.736 & 0.803 \\
\hline $16 \mathrm{~B}$ & INTB & 24 & $8.4 \mathrm{~b}$ & $17.2 \mathrm{~b}$ & $14.2 \mathrm{~b}$ & 0.925 & 0.826 & 0.879 \\
\hline
\end{tabular}

Layer (means of fields $12 \mathrm{~B}, 12 \mathrm{C}, 16 \mathrm{~A}$ and $16 \mathrm{~B}$ )

$\begin{array}{rrrrrrrr}0-10 \mathrm{~cm} & 32 & 14.0 \mathrm{a} & 26.8 \mathrm{a} & 18.1 \mathrm{a} & 0.863 & 0.548 & 0.682 \\ 10-25 \mathrm{~cm} & 32 & 8.0 \mathrm{~b} & 16.9 \mathrm{~b} & 15.4 \mathrm{~b} & 0.918 & 0.555 & 0.605 \\ 25-40 \mathrm{~cm} & 32 & 4.1 \mathrm{c} & 8.4 \mathrm{c} & 8.5 \mathrm{c} & 0.928 & 0.092 & 0.143\end{array}$

Year (means of fields $12 \mathrm{~B}, 12 \mathrm{C}, 16 \mathrm{~A}$ and $16 \mathrm{~B}$ )

\begin{tabular}{llllllll}
1987 & 48 & 8.6 & 16.9 & 13.3 & 0.941 & 0.764 & 0.806 \\
1988 & 48 & 8.6 & 17.8 & 14.6 & 0.934 & 0.692 & 0.780 \\
\hline
\end{tabular}

1 Means of $0-10,10-25 \mathrm{~cm}$ and $25-40 \mathrm{~cm}$ layers.

2 Variants: see Table 2.

$3 n=$ number of samples.

${ }_{4}$ Differences between means are significant at $P<0.001$ when the letters following the mean value in a column are different. 
large number of samples has to be used. To determine complex constraints of soil structure, moisture, oxygen, and soil organisms on $\mathrm{N}$ mineralization the use of intact soil cores may be indispensable. Another improvement may be to compare insitu measurements of $\mathrm{N}$ mineralization (Raison et al., 1987) with laboratory incubation methods; we started such a comparison in 1990.

Potential N-mineralization rates in soil samples from the $40-100 \mathrm{~cm}$ layers were relatively high, probably due to the high organic matter contents of these layers as a result of their geological history. Since these peat-containing layers are not normally disturbed in the field, whereas they are homogenized for laboratory incubation of samples, we doubt whether these rates were achieved in the undisturbed field situation. Therefore, $\mathrm{N}$ mineralization from soil layers below $40 \mathrm{~cm}$ was not taken into account in our $\mathrm{N}$-balance calculations; thus we perhaps underestimated $\mathrm{N}$ mineralization.

The solid fraction of the pig slurry mainly contained organic $\mathrm{N}$, from which the equivalent of $58 \mathrm{~kg} \mathrm{ha}^{-1}$ was mineralized during 24 weeks at $20^{\circ} \mathrm{C}$. This partly accounted for the higher potential $\mathrm{N}$ mineralization rates of manured integrated fields (16A, 16B, 12C) compared with conventional field 12B in 1987 (Fig. 2 and Table 4).

Compost contained very little inorganic $\mathrm{N}$ and had a low $\mathrm{N}$ mineralization rate; thus it hardly contributed to the $\mathrm{N}$ supply of the sugar beet crops in 1988. The slow mineralization also prevented $\mathrm{N}$ losses during the winter '87/' 88 . However, applications of compost contribute substantially to the maintenance of soil organic matter and organic- $\mathrm{N}$ levels in integrated management.

Simulation of $\mathrm{C}$ and $\mathrm{N}$ turnover of organic matter (inputs) can be used, when rate measurements are not available, as a first estimate for rates of $\mathrm{N}$ mineralization (van Faassen \& Smilde, 1985; van Faassen \& van Dijk, 1987). In this approach, turnover of organic matter is coupled with growth and development of the microbial biomass. Preliminary work with this model has shown that different rates of $\mathrm{N}$ mineralization may result, depending on the organic matter inputs from the previous crop(s). Turnover of crop residues and SOM through the microbial biomass had a tendency to decrease the variation in $\mathrm{N}$-mineralization rates between the years of a crop rotation (van Faassen, unpublished).

\section{Microbial biomass ( $N$ flush)}

Microbial biomass may be a sizable pool of labile $\mathrm{N}$ and may contribute substantially to $\mathrm{N}$ mineralization during incubation of soil samples. We found a significant correlation $(P<0.01)$ between potential $\mathrm{N}$-mineralization rates and $\mathrm{N}$ flushes for samples of $0-40 \mathrm{~cm}$ layers from the INT fields $16 \mathrm{~A}, 16 \mathrm{~B}$, and MT field $12 \mathrm{C}$; no significant correlation was found for samples from CONV field 12B. For samples from the layers $0-10$ and $10-25 \mathrm{~cm}$ from all four fields, $\mathrm{N}$ mineralization and $\mathrm{N}$ flush were significantly correlated $(P<0.01$ ), but not for samples from the $25-40 \mathrm{~cm}$ layer (Table 5). Analysis of variance showed, besides significant effects of field (management) and layer, also significant interaction effects of year $\times$ layer, field $\times$ layer or year $\times$ layer $\times$ field. These results show that a simple relation between $N$ mineralization and $\mathrm{N}$ flush, as an estimate of microbial biomass, does not always exist. 
Trends in soil organic matter and $N$ contents

The starting levels of SOM and total-N contents on blocks A and B showed a tendency to differentiate into four levels as a result of changes in management (Fig. 5). As expected, the high SOM content of block A could not be maintained under conventional management, but total $\mathrm{N}$ showed a more conservative trend than

\section{Organic matter (\%)}

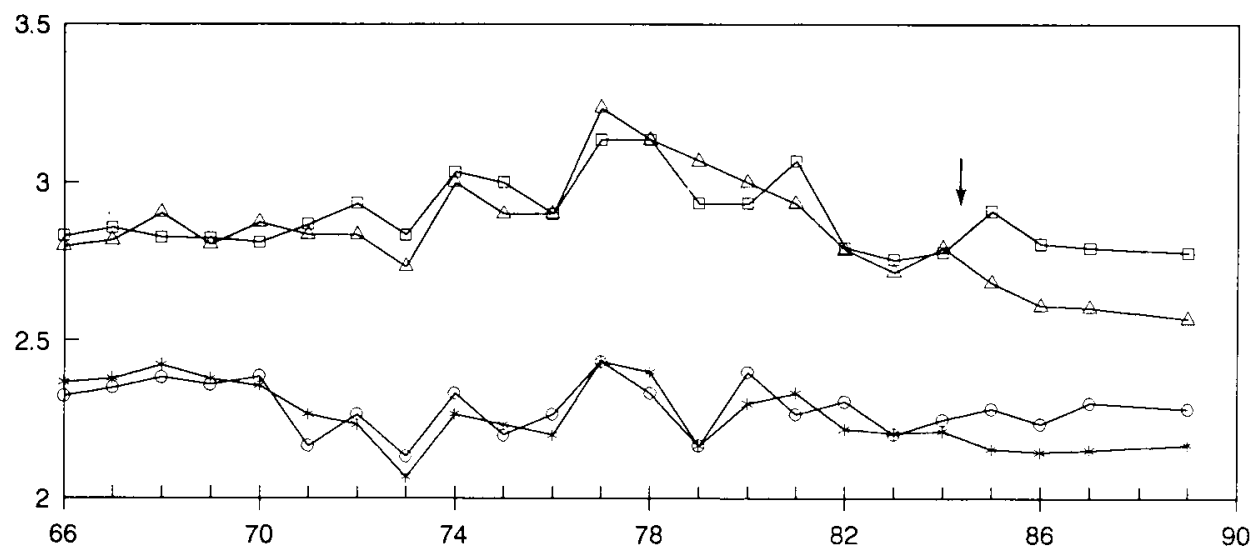

Total N (\%)

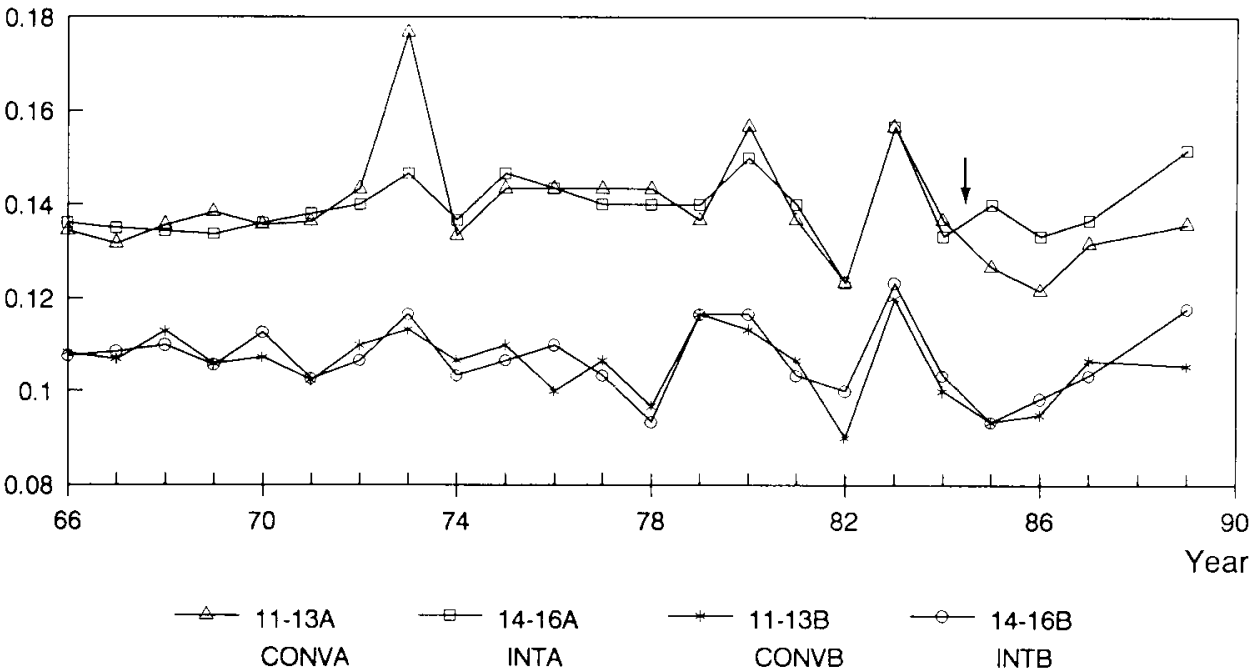

Fig. 5. Trends in soil organic matter and total-N contents in 0-25 cm layer, period 1966-1989. Each point represents the average value for three fields that have been part of the variants CONVA, CONVB, INTA and INTB since autumn 1985. Variants: see Table 2. Arrow $=$ start of conventional and integrated management. 
SOM. The low SOM content of block B also decreased slightly under conventional management, but total $\mathrm{N}$ was again more conservative than SOM. Integrated management, on block A as well as on block B, more or less maintained SOM content, but total $\mathrm{N}$ had a tendency to increase under these variants. A change in SOM and/or total-N content meant that steady-state conditions did not (yet) apply.

Equilibrium or steady-state means that net $\mathrm{N}$ mineralization must be compensated for by inputs of organic $\mathbf{N}$ from crop residues and organic manures. In the long term, steady-state conditions will determine the contribution of $\mathrm{N}$ mineralization to $\mathrm{N}$ supply of crops. Within a rotation cycle the organic-N pool will fluctuate. However, small changes in the very large pool of soil organic $\mathrm{N}$ cannot be quantified accurately. An absolute change in soil organic $\mathrm{N}$ of $0.01 \%$ represents about $300 \mathrm{~kg}$ $\mathrm{ha}^{-1}$ for the $0-25 \mathrm{~cm}$ layer (Legg \& Meisinger, 1982). A more accurate, quantitative confirmation of the trends in SOM and total-N levels in Figure 5 has to await results from a longer period.

\section{$N$ losses to the environment}

The magnitude of the $\mathrm{N}$ losses due to denitrification, nitrate leaching and $\mathrm{NH}_{3}$ volatilization strongly depends on weather conditions and soil management. By making separate $\mathrm{N}$-balance sheets over parts of the growing season, it is easier to relate $\mathrm{N}$ losses to the occurrence of a particular process, based on the prevailing weather and soil conditions, and on plant development during that period. Figure 6 gives an example for winter wheat in 1986. Crop N-uptake was simulated based on data from periodic harvests, and $\mathrm{N}$ mineralization was simulated based on potential rates measured in the laboratory, corrected for temperature. The resultant mineral- $\mathrm{N}$ content in soil was then calculated from Equation 1. Heavy rainfall, 50 $\mathrm{mm}$ within three days in June 1986, when soil nitrate levels were still high, may account for a nitrate- $\mathrm{N}$ loss of $60 \mathrm{~kg} \mathrm{ha}^{-1}$ in field $16 \mathrm{~A}$ and $37 \mathrm{~kg} \mathrm{ha}^{-1}$ in field $12 \mathrm{~B}$, probably by denitrification (Fig. 6). However, near the end of the growing season measured $\mathrm{N}_{\mathrm{i}}$ in field 12B almost equaled the amount calculated from the $\mathrm{N}_{i}$ balance, whereas for field $16 \mathrm{~A}$ an $\mathrm{N}$ deficit of about $50 \mathrm{~kg} \mathrm{ha}^{-1}$ persisted. Although denitrification is a plausible explanation for the calculated deficit in the inorganic- $\mathrm{N}$ balance of field 16A (Fig. 2a), overestimation of $\mathrm{N}$ mineralization may be an alternative explanation. Further evidence to support the role of denitrification in field 16A, but not in field 12B, stems from laboratory measurements: soil cores from field 16A showed higher rates of respiration than soil cores from field 12B, and only in the cores from field 16A was denitrification found (van Faassen, unpublished).

The application of manure to field 16A in May 1987, under wet conditions, may also have promoted denitrification, because it supplied a carbon source, while the oxygen supply was limited due to soil compaction by heavy machinery. Minimum tillage may also have furthered denitrification in the MT variants, since it concentrated crop residues in the compacted $0-5 \mathrm{~cm}$ layer with fewer gas-filled soil pores than in the other variants.

When $\mathrm{N}$ mineralized from crop residues in autumn is not taken up by a green ma- 


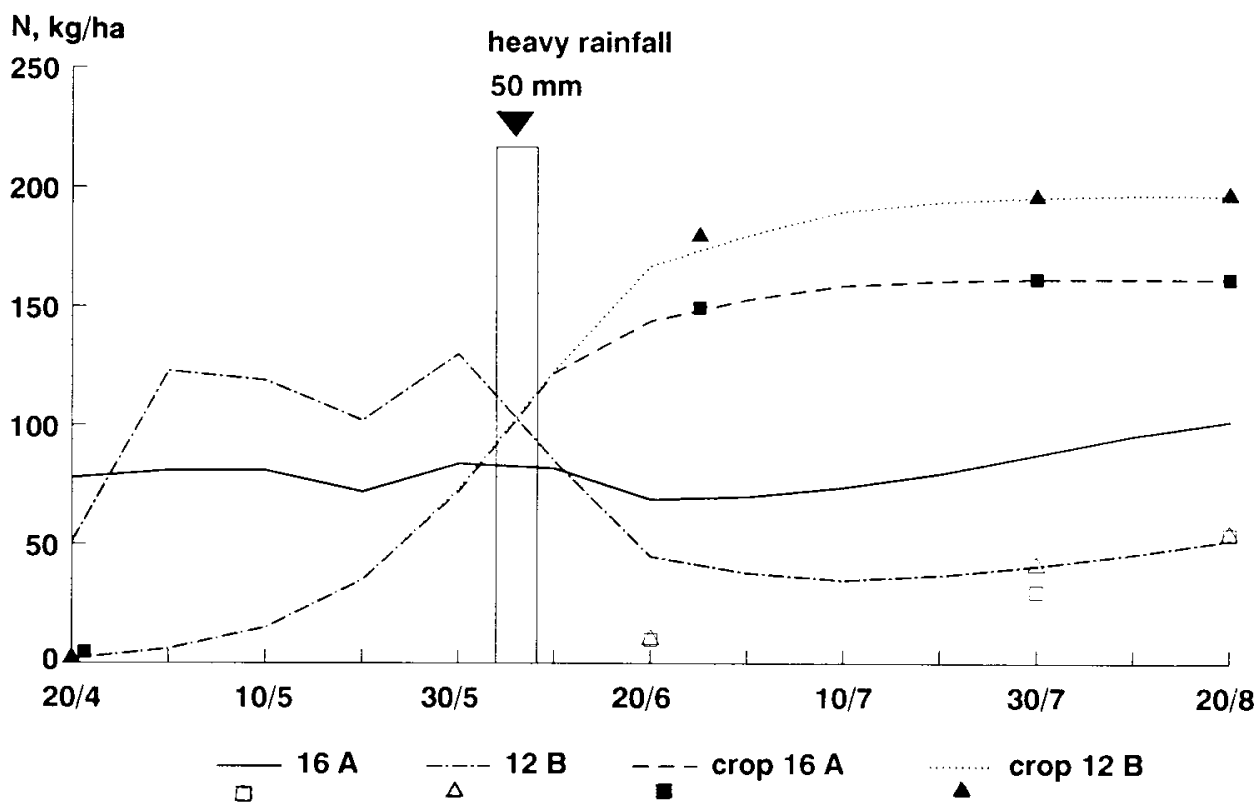

Fig. 6. Simulated N uptake (lines) by winter wheat in 1986, for CONV field 12B and INT field 16A, and simulated amount of inorganic $\mathrm{N}(\mathrm{Nmin})$, for field 12B and field 16A, present in the soil profile $(0-100$ $\mathrm{cm}$ layer) during the growing season based on inorganic- $\mathrm{N}$ balance calculations. Measured amounts (symbols) of $\mathrm{N}$ taken up by the crop $(12 \mathrm{~B}, 16 \mathrm{~A})$ and of mineral $\mathrm{N}$ in the soil profile $(12 \mathrm{~B}, 16 \mathrm{~A})$.

nure crop or immobilized in the microbial biomass after addition of organic manure, nitrate can accumulate until it is leached by surplus winter rainfall. A comparison of the amounts of nitrate-N present in the soil profile before and after winter gave a first estimate of the amounts of nitrate lost, by leaching and/or denitrification (Table 6). In November 1986, more nitrate was found in fields where potatoes had been grown, and also in deeper layers, than after cereal crops and after sugar beet. This accounts for the fact that on average more nitrate was lost during this winter from the fields where potatoes had been grown. Because of the position of

Table 6. Mean and range of nitrate- $\mathrm{N}$ contents $\left(\mathrm{kg} \mathrm{ha}^{-1}\right)$ in the $0-60 \mathrm{~cm}$ layer of the fields in November 1986 and 3 months later; rainfall during this period was $248 \mathrm{~mm}$.

\begin{tabular}{llccc}
\hline Crop (1986) & $n^{1}$ & 18 Nov'86 & 18 Febr '87 & $\Delta$ N ('N-loss') \\
Potatoes & 7 & $52(36-65)$ & $28(15-36)$ & $24(21-33)$ \\
Barley & 6 & $27(24-31)$ & $23(16-28)$ & $4(-1-10)$ \\
Wheat & 5 & $26(12-45)$ & $21(14-32)$ & $5(-4-13)$ \\
Sugar beet & 5 & $16(13-26)$ & $16(4-32)$ & $0(-4-8)$ \\
\hline
\end{tabular}

$1 n=$ number of fields. 
the drains, measurements of nitrate concentrations could not be used to distinguish effects of the management systems or of the crops.

From the literature no direct measurements of the leaching of nitrate following the growth of potatoes are known to us. In a review it has been concluded that potatoes are less effective in depleting the soil of mineral $\mathrm{N}$ than, for instance, cereals or sugar beet (Prins et al., 1988). This may increase the risk of nitrate leaching after the growth of potatoes. In Nagele, $25 \mathrm{~km}$ from Marknesse in the same polder, two reduced input systems have been compared with a conventional system on a farm scale since 1979 (Vereijken, 1986). Measurements at this site revealed that nitrate concentrations in the drainage water differed little under conventional and integrated management, but depended more on crop type. The highest concentrations were found following the growth of potatoes (W. P. Wadman, unpublished). The lowest nitrate concentrations were found under biodynamic management, but since this included, among other things, $40 \%$ grass in a 10-year rotation, it could not be directly compared with the other two systems. Measures directed to reduce nitrate leaching might also further reduce nitrate leaching under the conventional and integrated management systems.

Some $\mathrm{NH}_{3}$ may have volatilized from surface-applied manure in May 1987, since part of the manure $\mathrm{N}$ was present as $\mathrm{NH}_{4}-\mathrm{N}$. The high pH of this soil (7.6) would promote $\mathrm{NH}_{3}$ volatilization.

$\mathrm{NH}_{3}$ volatilization from the crops to the atmosphere may have contributed to $\mathrm{N}$ loss during periods of crop senescence (Nielsen et al., 1988). For this process only indirect evidence can be derived from $\mathrm{N}$ balance calculations, since no direct measurements were made.

To decrease $\mathrm{N}$ losses to the environment, and to improve $\mathrm{N}$ efficiency, high concentrations of $\mathrm{N}_{\mathrm{i}}$ should be avoided, especially in periods when losses are most likely to occur. This requires a shift to smaller amounts of fertilizer $\mathrm{N}_{\mathrm{i}}$ and/or split applications, the use of slow-release organic- $\mathrm{N}$ fertilizers such as compost, and a greater contribution of soil $\mathrm{N}$ mineralization. Furthermore, during periods without crop $\mathrm{N}$ uptake, $\mathrm{N}$ conservation should be promoted through the use of green manures, or through application of crop residues with a high $\mathrm{C} / \mathrm{N}$ ratio, which immobilize N.

\section{Conclusions}

- During the first three of four years after a shift from conventional (high input) to integrated (reduced input) management, on a calcareous silt loam soil, large deficits were calculated for the inorganic- $\mathrm{N}$ balance, suggesting high $\mathrm{N}$ losses in both systems, especially in the wet years 1987 and 1988 .

- The uncertainty about actual $\mathrm{N}$ losses mainly depended on the uncertainty in the calculated net $\mathrm{N}$ mineralization for field conditions, based on laboratory incubation of soil samples. Especially uncertain was the contribution of the layer $40-100 \mathrm{~cm}$, with a rather high organic matter content, to $\mathrm{N}$ supply of the crops.

- The soil organic matter and total-N contents showed a tendency to differentiate from their original two levels, on blocks A and B, into four levels as a result of 
changes in management. The next years will show which new steady-state levels will eventually result from integrated or conventional management.

- Correlations between $\mathrm{N}$ mineralization rates and biomass- $\mathrm{N}$ flush of soil samples were found to be situation-dependent.

- On fields with initial organic matter levels of $2.2 \%$ and $2.7 \%$, crop yields under integrated management were on average $83 \%$ and $88 \%$, respectively, of crop yields under conventional management.

- In the integrated system, the spring application of pig manure had to be changed to autumn application of spent mushroom compost, to prevent $\mathrm{N}$ loss by $\mathrm{NH}_{3}$ volatilization and by denitrification. The use of compost is also needed to maintain a high level of soil organic $\mathrm{N}$.

- To minimize the risk of $\mathrm{N}$ losses to the environment, soil inorganic $\mathrm{N}$ concentrations should be kept low, especially in periods when no active crop is present and $\mathrm{N}$ losses are most likely to occur.

\section{Acknowledgements}

This work was supported by the Netherlands Integrated Soil Research Programme.

\section{References}

Brussaard, L., M. J. Kooistra, G. Lebbink \& J. A. van Veen, 1988. The Dutch programme on soil ecology of arable farming systems. 1. Objectives, approach and some preliminary results. Ecological Bulletins 39: 35-40.

Faassen, H. G. van \& K. W. Smilde, 1985. Organic matter and nitrogen turnover in soils. In: B. T. Kang \& J. van der Heide (Eds), Nitrogen management for farming systems in humid and subhumid tropics, p. 39-55. Institute for Soil Fertility / International Institute of Tropical Agriculture, Haren / Ibadan.

Faassen, H. G. van \& H. van Dijk, 1987. Manure as a source of nitrogen and phosporus in soils. In: H. G. van der Meer, R. J. Unwin, T. A. van Dijk \& G. C. Ennik (Eds), Animal manures on grassland and fodder crops, fertilizer or waste?, p. 27-45. Developments in Plant and Soil Sciences, Vol. 30. Martinus Nijhoff, Dordrecht.

Jenkinson, D. S. \& D. S. Powlson, 1976. The effects of biocidal treatments on metabolism in soil. Soil Biology and Biochemistry 8: 209-213.

Kolenbrander, G. J., 1982. Fertilizers and pollution. In: Indian Society of Soil Science. Transactions 12th International Congress of Soil Science (New Delhi) Vol. 5, p. 248-266.

Kooistra, M. J., G. Lebbink \& L. Brussaard, 1989. The Dutch programme on soil ecology of arable farming systems. II. Geogenesis, agricultural history, field site characteristics and present farming systems at the Lovinkhoeve experimental farm. Agriculture Ecosystems and Environment 27: 361-387.

Kroeze, C., H. G. van Faassen \& P. C. de Ruiter, 1989. Potential denitrification rates in acid soils under pine forest. Netherlands Journal of Agricultural Science 37: 345-354.

Legg, J. O. \& J. J. Meisinger, 1982. Soil nitrogen budgets. In: F. J. Stevenson (Ed.), Nitrogen in agricultural soils. Agronomy 22: 503-566.

Lopez-Real, J. M., 1986. Sustainable agriculture: the microbial potential - the microbiologist's challenge. In: J. M. Lopez-Real \& R. D. Hodges (Eds), The role of microorganisms in a sustainable agriculture, p. 1-8. AB Academic Publishers, Berkhamstead, UK.

Neeteson, J. J., 1989. Assessment of fertilizer nitrogen requirement of potatoes and sugar beets. Doctoral Thesis, Wageningen Agricultural University, $141 \mathrm{pp}$. 
Nielsen, N. E., J. K. Schørring \& H. E. Jensen, 1988. Efficiency of fertilizer nitrogen uptake by barley. In: D. S. Jenkinson \& K. A. Smith (Eds), Nitrogen efficiency in agricultural soils, p. 62-72. Elsevier Applied Science Püblishers, Barking, UK.

Noordwijk, M. van, 1987. Methods for quantification of root distribution pattern and root dynamics in the field. In: Methodology of soil-K research, p. 263-281. International Potash Institute, Bern.

Prins, W. H., K. Dilz \& J. J. Neetseson, 1988. Current recommendations for nitrogen fertilisation within the EEC in relation to nitrate leaching. Proceedings No 276. The Fertiliser Society, London, $27 \mathrm{pp}$.

Raison, R. J., M. J. Connell \& P. K. Khanna, 1987. Methodology for studying fluxes of soil mineral-N in situ. Soil Biology and Biochemistry 19: 521-530.

Vereijken, P., 1986. From conventional to integrated agriculture. Netherlands Journal of Agricultural Science 34: 387-393. 